\title{
DiEZ AÑOS DEL SEMINARIO CINE Y DERECHO
}

\author{
Sergio Pérez González \\ CO-COORDINADOR DEL SEMINARIO CINE Y DERECHO \\ UNIVERSIDAD DE LA RIOJA
}

Tras diez años en antena, el Seminario Cine y Derecho debe una explicación. Y es que una década emitiendo hace dudar a cualquier espectador, así que esa explicación que debe el Seminario (que debemos los profesores Raúl Susín Betrán, David San Martín Segura y quien suscribe) la pagamos ahora en forma de crónica sumaria, que es la crónica de los motivos que nos llevaron a palpar el Derecho -a zarandearlo o a acariciarlo- a través de horas y horas de luces proyectadas.

El Derecho, como todo, se enseña de maneras muy diversas. La misma escritura del Derecho es, en cierto modo, pedagógica. Se manifiesta en códigos que encriptan deberes o disposiciones; luego se explica en comentarios que se empeñan en buscarle otros itinerarios lógicos; y en manuales que, a fuerza de glosas sedimentadas, pretenden una comprensión extendida, universal, universitaria. Y en esas estábamos, aprendiendo el Derecho en la Universidad -o enseñándolo, que es casi lo mismo-, cuando empezamos a notar que los conceptos se escapaban del recinto, bajo las puertas, por entre las rendijas... y reaparecían en nuestras pantallas, como una estrella no invitada. Las categorías jurídicas se nos colaban en las películas, viciaban los metrajes y arruinaban el mero entretenimiento pasivo... hasta que lo asumimos.

El lienzo cinematográfico es de un tejido blanco, sensible, en el que todo deja marca, incluso las sutilezas jurídicas; y las marcas, reproducidas en ese dinamismo encuadrado de la película, generan impresiones turbadoras, como las de esos flipbooks que toman vida al ser hojeados con el pulgar: formas inusitadas, sentidos impredecibles que no pueden escribirse ni leerse. Si el arte escarba en nuestra elementalidad, el cine -que es el arte de nuestra actualidad epistémica- consolida, complementa o desmiente nuestras lógicas más asentadas, incluidas las jurídicas. Porque el Derecho está repleto de virajes y aun circularidades, y en ese mareo semántico las películas ofrecen pautas para una comprensión sensitiva que tritura y recompone en su caos de luces y sombras: una narrativa que conforma metarrelatos apuntalados, paradójicamente, por espejismos, por 
escenas sugestivas y contradictorias cargadas de eso que ZIZEK llama «signos materiales que resisten al significado (...), una especie de resonancia cruzada presimbólica» .

Así fue que hace diez años, al calor del Área de Filosofía del Derecho, comenzamos a proyectar algunos de esos «signos que resisten al significado» por las paredes de la Universidad. Y así fue que películas como Minority Report, Farenheit 451 o La maldición de Frankenstein, dieron sustancia -o se la quitaron- a categorías como libertad, seguridad o riesgo. El formato se ha mantenido desde entonces y han pasado dos lustros en los que, cada primavera, varios ponentes -llamémosles expertos del logos- proponen un tema formal para luego someterlo a los avatares de un film, vale decir, a la luz del mito. El debate posterior siempre ha resultado enriquecido por las maneras heterogéneas y contradictorias en que hemos sentido el Derecho, en que lo hemos experimentado mientras estábamos a aquel lado de la pantalla.

DELEUZE -condenado al logos, malgrè lui- puso en juego una dialéctica de tomos para clasificar esa experiencia cinematográfica en dos grandes momentos: la imagenmovimiento y la imagen-tiempo ${ }^{2}$. En el tránsito histórico de la una a la otra -desde aquel primer cine-ojo aséptico- el cine ha ido intensificando la interacción con el espectador, integrándole en el desarrollo mismo del film hasta fraguar un séptimo arte en el que las miserias de nuestros pervertidos cerebros (ZIZEK publicó una guía audiovisual al efecto: The Pervert's Guide to Cinema -2006-) actualizan el sentido del metraje. Se trata de esa modernidad emancipadora ${ }^{3}$ del cine que despunta con el neorrealismo y se institucionaliza con la nouvelle vague o el free cinema, corrientes todas asiduas a nuestro Seminario.

A golpe de debilidades demasiado humanas que se infiltraban en aquella captura de imágenes, el cine fue empapándose de vicios tan encriptados que no resultaban apreciables en ninguna medición, en ningún código escrito: esa inagotable realidad que siempre se dice insuficientemente, que no cabe en las palabras que transitan un aula. DELEUZE recoge en el concepto de imagen-tiempo la capacidad del cine para trasladar la clave del visionado a la tramitación rizomática de las películas que hace el espectador ${ }^{4}$; sentidos adquiridos en itinerarios que no pueden rastrearse, en imágenes-recuerdo $0^{5}$ que redimensionan una mirada, en imágenes-sueño que evocan un significado sintético, improbable pero operativo, o en imágenes-cristal, que son ese momento de la película en el que, sin saber por qué atravesados por lo que vemos en ellos y notamos en nosotros-, reímos o lloramos, por poco que, en buena lógica, nos importe el destino de los protagonistas.

${ }^{\mathrm{I}}$ ZiZEK, S., Lacrimae rerum: ensayos sobre cine moderno y ciberespacio, trad. Ramón Vilà Vernis, Barcelona, Debate, 2006, pág. 93.

${ }^{2}$ Respectivamente, Deleuze, G., La imagen-movimiento. Estudios sobre cine 1, trad. Irene Agoff, Barcelona, Paidós comunicación, I984; y DeLEUZE, G., La imagen-tiempo. Estudios sobre cine 2, trad. Irene Agoff, Barcelona, Paidós comunicación, I987.

${ }^{3}$ LipovetSKY, G. y SERROY, J., La pantalla global: cultura mediática y cine en la era hipermoderna, trad. Antonio Prometeo Moya, Barcelona, Anagrama, 2009, pág. I9.

${ }^{4}$ Deleuze, G., La imagen-tiempo, cit.

${ }^{5}$ Deleuze, G., La imagen-tiempo, cit., pág. 69.

${ }^{6}$ Deleuze, G., La imagen-tiempo, cit., pág. 82.

${ }^{7}$ Deleuze, G., La imagen-tiempo, cit., pág. 99. 
Es este cine-pensamiento ${ }^{8}$ el que eclosiona como (post)estructura de comprensión. El Derecho ha generado una ingente sucesión de significados intentando desentrañar los solapamientos conceptuales que martirizan al estudiante y enfadan al ciudadano. A pesar de ello, los lectores siguen buscando ese manual definitivo (y que defina): lo justo, lo legítimo, lo moral, lo privado, lo público, lo común, la obligación, el deber, la responsabilidad, la culpabilidad, la pena... Y sin embargo, a veces, una película permite cribar -en su bacanal sensorial, en insinuantes cruces de evocaciones y mundanidades- el Derecho adecuado o su ausencia debida, su contorno más ajustado a lo humano (o a otras divinidades).

Durante estos últimos diez años, el proyector del Aula Magna del edificio Quintiliano ha arrojado luces que advertían coyunturas y rezumaban transcendencias, como historias proyectadas sobre un cristal que las recoge y, a la vez, las deja pasar a planos de proyección más recónditos. En esas imágenes había trocitos de Derecho que se relacionaban en modos extraños, subvirtiendo las lógicas de los enunciados canónicos. Así, por ejemplo, casi todos convenimos que el abogado Atticus Finch hizo lo debido al no matar al ruiseñor, aunque tal vez no fuera lo que dicen los manuales; o así fue que una tarde algunos quisimos aplicarle un ordenamiento jurídico paralelo al Vampiro de Dusseldorf; o que nos alivió que Gran Jefe liberase a McMurphy cuando ya nadie volaba sobre el nido del cuco...

Los ponentes, que presentaron estas y otras más de cincuenta películas, disertaban sobre la validez, operatividad o extrapolación de los conceptos jurídicos implicados, pero ya sabían que sus propuestas no agotaban las posibilidades de acierto, porque el acierto jurídico es dinámico, como una película. Imbuidos en esa episteme cinematográfica que es la del hipercine ${ }^{9}$, pasábamos los discursos, las ordenaciones conceptuales, las palabras, por el tamiz de la experiencia cinematográfica. Y es que el mundo se rige ya por eso que LIPOVETSKY y SERROY titulan pantallasfera, todopantalla o pantallocracia ${ }^{\mathrm{I}}$ : si las salas de cine se vacían es, en parte, porque la sociedad -y la Universidad- ya están llenas del cine mismo. Tomarse en serio lo que el cine transmite es un modo de calibrar aquella fabulación como potencia creadora ${ }^{\text {II }}$ de la que hablara BERGSON. Porque reconcebir las tensiones conceptuales, las insuficiencias del logos, mediante el visionado cinematográfico es un modo de comprenderlas en tanto que sentirlas, en tanto que darlas por vividas: «el cine se ha convertido en educador de una mirada global» ${ }^{12}$.

Pero el cine está sujeto a la voracidad de su propia technè. Los formatos de su intermitencia lumínica no dejan de explorar, de ensayar y de errar (largometrajes, cortometrajes, micrometrajes... share life in motion es la invitación de la app vine para que la vida misma sea una película en tiempo real). Quizá su último gran acierto sean las series, esos films interrumpidos mediante los que los personajes se alojan en nuestras casas

\footnotetext{
${ }^{8}$ DeleuZe, G., La imagen-tiempo, cit., pág. 224.

${ }^{9}$ Lipovetsky, G. y Serroy, J., La pantalla global, cit., pág. I6.

${ }^{\text {Io }}$ LipovetSky, G. y Serroy, J., La pantalla global, cit., págs. II, I3 y 22.

${ }^{\text {I }}$ Bergson, H., Las dos fuentes de la moral $y$ de la religión, trad. Jaime de Salas y José Atencia, Madrid, Tecnos, I996.

${ }^{12}$ LipovetSKY, G. y SerRoy, J., La pantalla global, cit., pág. 28.
} 
durante meses o años. El Seminario Cine y Derecho -jel XI!- les dará la palabra o, mejor dicho, la luz.

Si hace una década notábamos que el Derecho salía de la Universidad para colarse en las pantallas, ahora, tras diez años de Seminario, ya sabemos que era el cine el que estaba inundando el mundo, incluida la Universidad. Había que asumirlo.

\section{Bibliografía}

Bergson, H., Las dos fuentes de la moral y de la religión, trad. Jaime de Salas y José Atencia, Madrid, Tecnos, 1996.

DeleuZe, G., La imagen-movimiento. Estudios sobre cine 1, trad. Irene Agoff, Barcelona, Paidós comunicación, 1984 .

— La imagen-tiempo. Estudios sobre cine 2, trad. Irene Agoff, Barcelona, Paidós comunicación, 1987.

LIPOVETSKY, G. y SERROY, J., La pantalla global: cultura mediática y cine en la era hipermoderna, trad. Antonio Prometeo Moya, Barcelona, Anagrama, 2009.

ZiZeK, S., Lacrimae rerum: ensayos sobre cine moderno y ciberespacio, trad. Ramón Vilà Vernis, Barcelona, Debate, 2006. 